\title{
Relationships between Fish Sizes and Otolith Sizes of Whiting (Merlangius merlangus Linnaeus, 1758) from the Western Black Sea
}

\author{
Taner Yıldız' (1)
}

Cite this article as: Yıldız, T. (2020). Relationships between fish sizes and otolith sizes of whiting (Merlangius merlangus linnaeus, 1758) from the Western Black Sea. Aquatic Sciences and Engineering, 35(3), 69-74.

ORCID IDs of the author:

T.Y. 0000-0003-3140-5118

'istanbul University, Faculty of Aquatic Sciences, Istanbul, Turkey

Submitted:

27.12.2019

Revision Requested:

16.02.2020

Revision Requested: 20.02.2020

Accepted:

22.02.2020

Online published:

24.03.2020

Correspondence:

Taner Yıldız

E-mail:

yldztnr@istanbul.edu.tr

(c) Copyright 2020 by Aquatic

Sciences and Engineering

Available online at

https://dergipark.org.tr/ase

\begin{abstract}
The objective of this study was to determine the regressions between otolith sizes and shape indices vs. fish length, and weight of whiting, Merlangius merlangus (Linnaeus, 1758), from the Black Sea. Samples were collected randomly from commercial bottom trawlers between November 2017 and January 2018 in the western Black Sea. No differences were found in otolith size and indices by means of otolith position while a distinct difference by sexes was detected. Strong relations with high descriptive coefficients were found between otolith sizes and weight and fish length and weight. However, the regression relationships between otolith shape indices and fish length and weight were defined as very weak. As a conclusion, it can be emphasized that the otolith sizes and weight of whiting can be used for the determination of the size and weight of the fish.
\end{abstract}

Keywords: Otolith dimensions, fish size, whiting, Black Sea

\section{INTRODUCTION}

Whiting has a wide distribution including the Black Sea, the Azov Sea, the Marmara, the Aegean Sea and the Adriatic Sea (Whitehead et al., 1986). Whiting, one of the two members of the Gadidae family distributed in the Black Sea, is one of the most important target species in the Black Sea bottom trawl fishery.

In the Black Sea, whiting is quite dominant in terms of catch composition of demersal species (Genç et al., 2002). It is caught by bottom gillnets as well as bottom trawl nets in the central and eastern part of the Black Sea. Due to the high commercial value and the traditional consumption behavior of the public, the market is always in high demand.

In all fish except sharks, stingrays, and lampreys (Campana, 2004) on both sides of the head, behind the eyes, adjacent to the brain, in the channels of the inner ear (Smale et al., 1995) otoliths, small and white structures (Campana, 2004) are formed as a result of regular accumulation of calcium carbonate crystals during the life of the fish (Furlani et al., 2007). Annual growth rings in otoliths during fish growth are similar to age occurrences in trees (Casselman, 1983). As the fish grow, the otoliths continue to grow, and there is always a strong relationship between otolith size and fish size (Hunt, 1992). Studies on this relationship have increased in different aspects of fish and fisheries biology studies in recent years. Otoliths vary in size and shape from one fish group to another. It is even characteristic for the genus and species of fish (Demir, 1965). Otolith morphology is used in studies in many different areas for fish biology; anatomy of fish species, identification of new fish species, taxonomic revisions of fish taxons, determination of phylogenetic relationships, studies of eco-morphology, determination of similarities between fish growth and otolith growth (Campana, 1999; Bostancl et al., 2012). The relationship between fish size and otolith size has been utilized to calculate the size or age of prey obtained from the 
stomach content of several fishes (Pitcher, 1980; Bailey \& Ainley, 1982; Jobling \& Breiby, 1986; Granadeiro \& Silva, 2000; Javor et al. 2011). In addition, otolith shape can be described in many ways, one of the simplest being manual distance measurement. Such measurements can be used in a series of mathematical equations that calculate shape indices (Burke et al., 2008)

Due to ecological and economic importance of the Black Sea whiting, although there have been many studies on the distribution and biomass (Çiloğlu et al., 2001; Genç et al., 2002; Gönener \& Bilgin, 2006; Gönener \& Bilgin, 2010), population parameters (Düzgüneş \& Karaçam, 1990; Samsun et al., 1994; İşmen, 2002; Özdemir et al., 2006), age and growth (Polat \& Gümüş, 1996; Yildiz and Karakulak, 2019), reproduction biology (Reşat, 2013; Mazlum \& Bilgin, 2014), feeding regime and diet (Samsun et al., 2011; Mazlum \& Bilgin, 2014) and length-weight relationship (Kalaycı et al., 2007; Ak et al., 2009; Van et al., 2019; Yıldız et al., 2018) no publication has been found on the relationship between otolith sizes and fish sizes. However, only one study revealed the otolith asymmetry levels of whiting in the Middle Black Sea (Kontaş et al., 2018). In the light of the above-mentioned motivations, the aim of this study was to determine the relationship between the length and weight of whiting and various dimensions of otolith.

\section{MATERIAL AND METHOD}

The whiting samples used in the study were randomly sampled from the bottom trawler vessels engaged in commercial fishing in the western Black Sea between November 2017 and January 2018. Total length, total weight, and sex of each individual were recorded in the laboratory. Sex determination was made macroscopically using color and structural differences in the gonads. The significance of sex-related difference in length distribution between male and female individuals was checked with the Kolmogorov-Smirnov test $(\alpha=0.05)$. 260 sagittal otoliths from 130 whiting specimens measured by biometric measurements were removed and fixed in a dry manner. Images of otoliths were recorded using a Leica DC 500 camera system connected to a Leica S8 APO stereo microscope and image analysis program (Leica Application Suite Version 4.3.0). Morphometric measurements such as length $(\mathrm{OL})$, width $(\mathrm{OW})$, perimeter $(\mathrm{OP})$ and area (OA) of the otoliths were performed on these images (Figure 1). Otolith area (OA) was automatically calculated using the Leica Application Suite. Using these measurements, the otolith shape indices were calculated using the formulas given in Table 1 (Tuset et al. 2003). The right and left otoliths were weighed separately on a digital balance (Kern $A B J$ ) with a precision of $\pm 0.0001 \mathrm{~g}$, and the otolith weights (OWE) were recorded.

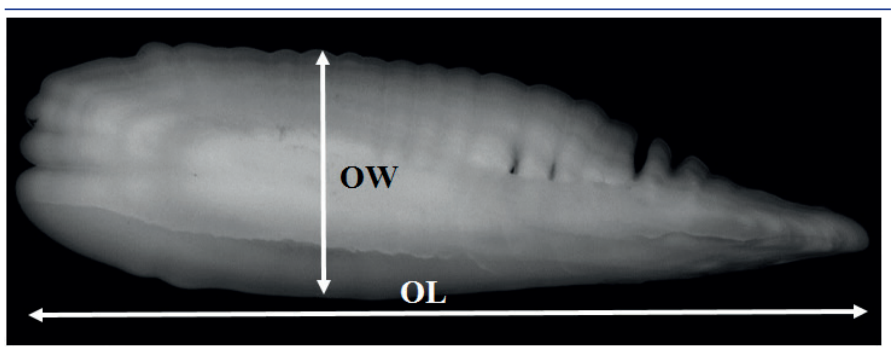

Figure 1. Whiting otolith and two basic morphometric measurements.
Descriptive statistics (mean, minimum and maximum values and standard deviation) of fish length and weight, otolith dimensions and

Table 1. The formulas of otolith shape indices.

\begin{tabular}{ll}
\hline Otolith shape indices & Formula \\
\hline Circularity & $\mathrm{OP} / \mathrm{OA}^{2}$ \\
Rectangularity & $\mathrm{OA} /(\mathrm{OL} \times \mathrm{OW})$ \\
Form factor & $(4 \mathrm{OA}) / \mathrm{OP}^{2}$ \\
Roundness & $(4 \mathrm{OA}) /\left(\mathrm{OL}^{2}\right)$ \\
Ellipticity & $(\mathrm{OL}-\mathrm{OW}) /(\mathrm{OL}+\mathrm{OW})$ \\
Aspect Ratio & $\mathrm{OL} / \mathrm{OW}$
\end{tabular}

shape indices were calculated. The dimensions of the otolith were correlated with the length and weight of the fish using linear and nonlinear (exponential) regression analyses. The relationships between the otolith dimensions were determined using regression analysis (Zar, 2010). The results of regression analysis, relationship types obtained, equation constants and descriptive coefficients showing the strength of the relationship were calculated. The significance of the difference in otolith size and shape indices depending on otolith position (right-left) and sex (male-female) was tested using Multivariate Analysis of Variance (MANOVA). Before the analysis, the Levene test was applied for the assumption of homogeneity of the variances. The non-homogeneous data were adapted to the homogeneous distribution with the $\log _{x+1}$ converter. All statistical tests were performed using R Programming (R Development Core Team, 2018).

\section{RESULTS}

Descriptive statistics of total length and weight values of male $(n=60)$ and female $(n=70)$ individuals are given in Table 2. While the average length was $17.5 \mathrm{~cm}$ for female and $13.4 \mathrm{~cm}$ for male, the mean weight was $44.37 \mathrm{~g}$ for females and $21.55 \mathrm{~g}$ for males (Table 2; Figure 2). The difference between the length-frequency distributions of the sexes was found significant $(p<0.05)$.

According to the results of the MANOVA test, the difference in morphometric values due to otolith position (right-left) was not statistically significant ( $p>0.05)$, but it was found to be significant due to sex (male-female) $(p<0.05)$. For this reason, regression relationships between fish length and weight and otolith dimensions $(\mathrm{OL}, \mathrm{OW}$, OA, OWE, OP) were calculated separately for sexes by combining the right-left otolith values with 260 otoliths (both right and left together). Considering the descriptive statistics of the otolith dimensions, it is seen that the mean values of the female individuals are greater than the males in all otolith sizes (Table 3).

Table 2. Descriptive statistics of fish length and weight by sex.

\begin{tabular}{lcccc}
\hline & \multicolumn{2}{c}{ TL } & \multicolumn{2}{c}{ TW } \\
\hline & + & $\delta$ & $q$ & 0 \\
\hline Min & 10.7 & 8.7 & 9.12 & 3.74 \\
Max & 22.9 & 21.1 & 95.54 & 75.49 \\
Mean & 17.5 & 13.4 & 44.37 & 21.55 \\
SD & \pm 2.53 & \pm 3.18 & \pm 18.49 & \pm 15.22
\end{tabular}



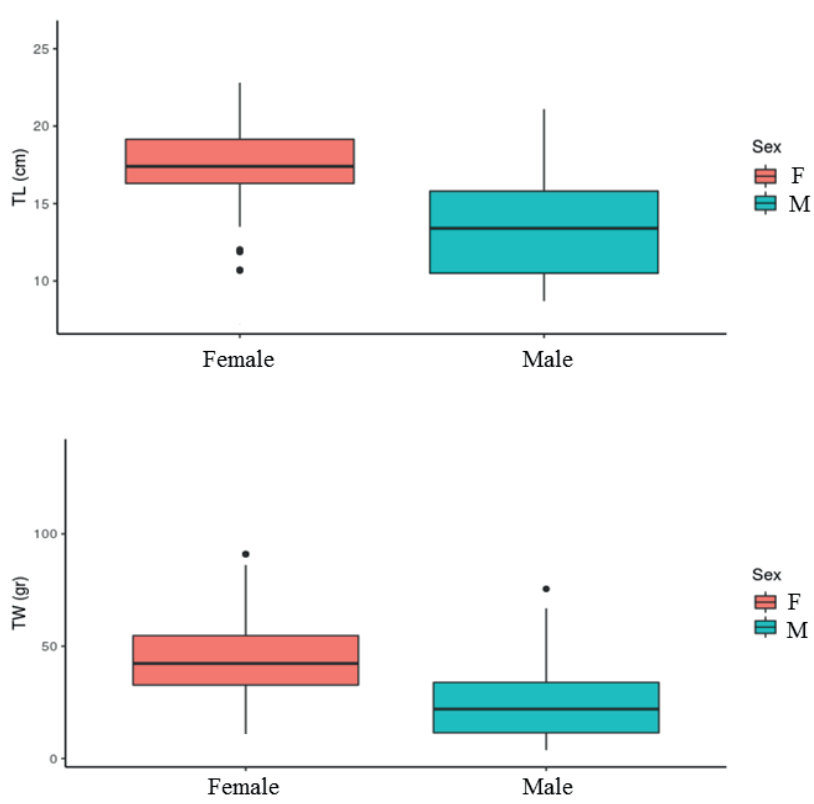

Figure 2. Boxplot of the total length (upper) and weight (lower) distributions by sex.

Table 3. Descriptive statistics of otolith morphometric values by sex.

\begin{tabular}{lccccc}
\hline & OL & OW & OA & OWE & OP \\
\hline \multicolumn{7}{c}{ O } \\
\hline Min & 5.517 & 1.887 & 7.443 & 0.0085 & 12.395 \\
Max & 12.894 & 4.137 & 38.108 & 0.0763 & 30.867 \\
Mean & 9.061 & 2.842 & 19.136 & 0.0325 & 20.426 \\
SD & \pm 1.431 & \pm 0.364 & \pm 5.321 & \pm 0.0128 & \pm 3.235 \\
\hline \multicolumn{7}{c}{$\hat{0}$} \\
\hline Min & 3.816 & 1.366 & 3.925 & 0.0032 & 8.685 \\
Max & 10.787 & 3.514 & 26.08 & 0.0481 & 24.185 \\
Mean & 6.937 & 2.279 & 12.021 & 0.0173 & 15.695 \\
SD & \pm 1.715 & \pm 0.493 & \pm 5.288 & \pm 0.0101 & \pm 3.899
\end{tabular}

Descriptive statistics of the otolith shape indices calculated on the basis of the measured dimensions of the otoliths are given in Table 4 for the sexes separately. According to the MANOVA results, the difference due to otolith position (right-left) is not statistically significant ( $p>0.05)$. The values of shape indices calculated for the sexes were also very close to each other and no statistical difference was observed ( $p>0.05)$.

As a result of regression analysis used to determine the relationship models between otolith dimensions with fish length and weight; the relationship types obtained (linear $(L)$ or exponential $(E)$ ), equation constants ( $a$ and $b$ ) and the coefficient of determination $\left(R^{2}\right)$ indicating the strength of the relationship are shown in Table 5. In both sexes, regressions between total length and weight with otolith morphometry were defined with a high coefficient of determinations. As it can be seen from the table, the descriptive coefficient of regression relations in male individuals was always higher than female individuals. While the relationships between male individuals are completely linear, the relationships between fish length and otolith dimensions in female individuals are mostly exponential.

The results of the regression analysis used to determine the equations between the otolith dimensions in the explanation of the otolith morphometry are shown in Table 5. Except for five relationships, regression relationships were defined linearly. The highest relationship was found between the otolith length and otolith perimeter for males.

The regression relationships between the shape indices and the fish length resulted in descriptive coefficients that were too low to be correlated with the fish length. Otolithic rectangularity does not show a significant relationship with fish length $\left(p>0.05 ; R^{2}=0.01\right)$.

\section{DISCUSSION}

In the otolith atlas of Tuset et al. (2008), the whiting otolith was described as; Shape: lanceoated, anterior region more globose than the posterior, margins lobed in the smaller otoliths. Sulcus acusticus: heterosulcoid, pseudo-ostiocaudal, median. Ostium: elliptic, broad, shorter than the cauda. Cauda: tubular, straight, as wide as the ostium, separated from the ostium by a solid bridge-like collum. Anterior region: round to irregular. Posterior region: sharply lanceolated. In this study, the whiting otoliths

Table 4. Descriptive statistics of otolith shape indices by sex.

\begin{tabular}{|c|c|c|c|c|c|c|}
\hline & Circularity & Rectangularity & Aspect ratio & Roundness & Form factor & Ellipticity \\
\hline Value & \multicolumn{6}{|c|}{ q } \\
\hline Min & 18.87 & 0.63 & 2.61 & 0.25 & 0.40 & 0.45 \\
\hline Max & 31.22 & 0.80 & 3.63 & 0.38 & 0.67 & 0.57 \\
\hline Mean & 22.23 & 0.73 & 3.18 & 0.29 & 0.57 & 0.52 \\
\hline SD & \pm 1.75 & \pm 0.02 & \pm 0.21 & \pm 0.02 & \pm 0.04 & \pm 0.02 \\
\hline \multicolumn{7}{|c|}{$0^{\pi}$} \\
\hline Min & 18.62 & 0.67 & 2.60 & 0.26 & 0.37 & 0.44 \\
\hline Max & 30.71 & 0.78 & 3.57 & 0.36 & 0.67 & 0.56 \\
\hline Mean & 21.37 & 0.73 & 3.02 & 0.31 & 0.59 & 0.50 \\
\hline SD & \pm 1.58 & \pm 0.02 & \pm 0.19 & \pm 0.02 & \pm 0.04 & \pm 0.02 \\
\hline
\end{tabular}


Table 5. Regression relationship parameters and descriptive coefficients between fish length and weight with otolith dimensions and among otolith dimensions by sex (E: exponential, L: linear).

\begin{tabular}{|c|c|c|c|c|c|c|c|c|}
\hline \multirow[b]{2}{*}{ Variables } & \multicolumn{4}{|c|}{ q } & \multicolumn{4}{|c|}{$\hat{0}$} \\
\hline & $a$ & $b$ & $R^{2}$ & Regression type & $a$ & $b$ & $R^{2}$ & Regression type \\
\hline TL-OL & 3.3712 & 0.55 & 0.8529 & $E$ & 0.5209 & -0.074 & 0.9334 & L \\
\hline TL-OW & 0.1275 & 0.6011 & 0.8597 & L & 0.1489 & 0.2753 & 0.9208 & L \\
\hline TL-OA & 3.1461 & 0.1005 & 0.9018 & E & 1.6213 & -9.8026 & 0.9519 & L \\
\hline TL-OWE & 0.0026 & 0.1398 & 0.9047 & E & 0.0031 & -0.0245 & 0.9419 & L \\
\hline TL-OP & 7.5228 & 0.0561 & 0.8867 & $E$ & 1.1768 & -0.1452 & 0.9221 & L \\
\hline TW-OL & 0.0619 & 6.2887 & 0.7634 & L & 0.1025 & 4.7278 & 0.8271 & L \\
\hline TW-OW & 0.0163 & 2.1136 & 0.8140 & L & 0.0293 & 1.647 & 0.8174 & L \\
\hline TW-OA & 0.2438 & 8.2102 & 0.8584 & L & 0.3274 & 4.966 & 0.8876 & L \\
\hline TW-OWE & 0.0006 & 0.0063 & 0.8584 & L & 0.0006 & 0.0037 & 0.8977 & $L$ \\
\hline TW-OP & 0.1439 & 13.978 & 0.8087 & L & 0.2318 & 10.7 & 0.8181 & $L$ \\
\hline OL-OW & 0.2318 & 0.7421 & 0.8287 & L & 0.2803 & 0.3346 & 0.9489 & L \\
\hline OL-OA & 3.5945 & -13.434 & 0.9354 & L & 1.5853 & 0.2766 & 0.9698 & E \\
\hline OL-OWE & 0.0029 & 0.260 & 0.9123 & $E$ & 0.001 & 0.389 & 0.9577 & E \\
\hline OL-OP & 2.2229 & 0.284 & 0.9677 & L & 2.2551 & 0.0504 & 0.9843 & L \\
\hline OW-OA & 14.151 & -21.091 & 0.9401 & L & 10.556 & -12.035 & 0.971 & L \\
\hline OW-OWE & 0.0018 & 1.0016 & 0.878 & $E$ & 0.0007 & 1.3382 & 0.938 & E \\
\hline OW-OP & 8.1976 & -2.8764 & 0.8533 & L & 7.6539 & -1.7479 & 0.9387 & L \\
\hline OA-OWE & 0.0023 & -0.0118 & 0.9272 & $\mathrm{~L}$ & 0.0019 & -0.0054 & 0.9679 & L \\
\hline OA-OP & 0.591 & 9.1176 & 0.9446 & L & 0.7217 & 7.02 & 0.9577 & $\mathrm{~L}$ \\
\hline OWE-OP & 242.44 & 12.526 & 0.9234 & L & 367.9 & 9.319 & 0.9231 & L \\
\hline
\end{tabular}

sampled in the western Black Sea have similar characteristics. Hehir (2003) stated that whiting otoliths have a thinner and flatter structure than other gadoid otoliths. Atılgan et al. (2010) also reported that the whiting otoliths have a relatively large and thickened structure compared to the body size. In this study, although the thickness of the whiting otoliths was not measured, a thickening was observed in the central part of the large otoliths.

Tuset et al. (2008) stated that the average otolith width of whiting is between $33.8 \%$ and $35.6 \%$ of the average otolith length. In this study, it was calculated that the ratio of average otolith width to average otolith length was between $27.5 \%$ and $38.5 \%$. Tuset et al. (2008) reported that the circularity is between 19.4 and 24.0 and the rectangularity is 0.5 . In this study, the circularity was calculated between 18.6 and 31.2 and the rectangularity was calculated between 0.66 and 0.79. Unfortunately, Tuset et al. (2008) did not give the length values of the specimens so a comparison of otolithic properties cannot be made.

When the right and left region otolith pairs are examined in terms of otolith dimensions, the absence of a statistically significant difference shows that otoliths can be used without distinguishing them from each other and that the choice of right or left otoliths can be made. For this reason, it can be said that the otolith morphometry studies with whiting can be evaluated without considering right-left otolith differences.
However, the difference between male and female individuals in otolith sizes is significantly different. It has been emphasized in many studies that female individuals in the whiting population always have bigger lengths than males (İşmen, 1995; Yıldız \& Karakulak 2019). Otolith dimensions are related to fish length, as fish length increases, so do otolith dimensions. Otolith sizes are also larger than males because female individuals always reach big lengths. In addition, it has been emphasized in many studies that the growth in male and female individuals is different, that females always reach higher asymptomatic length $\left(\mathrm{L}_{\mathrm{inf}}\right)$ and that there is an increase in the proportion of female individuals parallel to the increase in age and length in the population (İşmen, 1995; Çiloğlu, 1997; Samsun, 2005; Yıldız \& Karakulak, 2019).

According to the results of the regression analysis, there is a strong relationship between fish size and otolith dimensions of whiting. However, this relationship is exponential, not linear, especially in female individuals. In other words, it can be said that the linear relationship between otolith dimensions and total length is disrupted at a certain point in the life cycle of female individuals. This may be due to thickening of the whiting otoliths in the central region in older ages. Mineral accumulation in otoliths occurs more in the width of otoliths than otolith length. There is a strong relationship between fish weight and otolith dimensions. In contrast to fish size, these relationships are defined linearly in males and females. Researchers, working with organisms that 
feed on fish such as predator fish and marine mammals, try to determine the prey composition of the species they work in, using the shape and size of undigested otoliths in the stomach contents of these species (Campana, 2004). Owing to these studies, it is possible to understand the food chain in the sea by using otoliths (Smale et al., 1995). Moreover, by using the fish length-otolith size relationships, the prey size can be estimated from the otolith length obtained from the stomach contents. According to the results of this study, whiting otolith dimensions and weight can be used to determine fish length and weight in future studies.

Acknowledgementds: This study was funded by the Scientific Research Projects Coordination Unit of Istanbul University. Project number: FAB-2017-24719. The author thanks Dr. Uğur Uzer from Istanbul University for assisting with the laboratory part of the study.

Ethics committee approval: This study was performed in accordance with ethical standards of animal experiments.

Conflict of Interests: The author declares that there are no conflicts of interest.

\section{REFERENCES}

Ak, O., Kutlu, S., Genç, Y., \& Haliloglu, H.I. (2009). Length frequency, length-weight relationship and sex ratio of the whiting, Merlangius merlangus in the Black Sea, Turkey. Balıkesir Üniversitesi Fen Bilimleri Enstitüsü Dergisi, 11(2), 37-43.

Atılgan, E., Erbay, M., \& Aydın İ. (2010). Doğu Karadeniz'deki ekonomik bazi balik türlerinin otolit özellikleri. YUNUS Araştırma Bülteni, 10(3), 12-15.

Bailey, K.M., \& D.G. Ainley (1982). The dynamics of California sea lion predation on Pacific hake. Fisheries Research, 1, 163-176. [CrossRef]

Bostancı, D., Yılmaz S., Polat N., \& Kontaş, S. (2012). İskorpit Scorpaena porcus L., 1758'un otolit biyometri özellikleri. Karadeniz Fen Bilimleri Dergisi, 2(6), 59-68.

Burke, N., Brophy, D., \& King, P. A. (2008). Otolith shape analysis: its application for discriminating between stocks of Irish Sea and Celtic Sea herring (Clupea harengus) in the Irish Sea. ICES Journal of Marine Science, 65, 1670-1675. [CrossRef]

Campana, S. E. (1999). Chemistry and composition of fish otoliths: pathways, mechanisms and applications. Marine Ecology Progress Series, 188, 263-297. [CrossRef]

Campana, S.E. (2004). Photographic Atlas of Fish Otoliths of the Northwest Atlantic Ocean. Canadian Special Publication of Fisheries and Aquatic Sciences 133, NRC Research Press, 978-0-660-19108-9. [CrossRef]

Casselman, J. M. (1983). Age and growth assessment of fish from their calcified structures- techniques and tools. NOAA Tech Rep NMFS 8: 1-17.

Çiloğlu, E. 1997. Vertically distribution and population parameters of Merlangius merlangus euxinus Nordmann, 1840 on the east coasts of Trabzon, (in Turkish), Yüksek Lisans Tezi, İstanbul Üniversitesi. FBE, İstanbul, 66292.

Çiloglu, E., Sahin, C., Zengin, M., \& Genç Y. (2001). Dogu Karadeniz, Trabzon- Yomra sahillerinde mezgit (Merlangus merlangus euxinus Nord., 1840) balıgının bazı populasyon parametreleri ve üreme döneminin tespiti. Turkish Journal of Veterinary and Animal Sciences, 25, 831-837.

Demir, M. (1965). Balıkçוlık Biyolojisine Giriş. İstanbul Üniversitesi Fen Fakültesi Yayınları, 1129(64), 107

Düzgüneş, E., \& Karaçam, H. (1990). Doğu Karadeniz'deki mezgit (Gadus euxinus Nord., 1840) balıklarında bazı populasyon parametreleri, et verimi ve biyokimyasal kompozisyonu. Doğa: Turkish Journal of Zoology, 14, 345-352.

Furlani, D., Gales, R., \& Pemberton, D. (2007). Otoliths of Common Australian Temperate Fish A Photographic Guide, CSIRO Publishing, Australia. [CrossRef]

Genç, Y., Mutlu, C., Zengin, M., Aydın, I., Zengin, B., \& Tabak, I. (2002). Doğu Karadeniz'deki av gücünün demersal balık stokları üzerine etkisinin tespiti-sonuç raporu, T.C. Tarım ve Köy İşleri Bakanlığı Tarımsal Araştırmalar Genel Müdürlüğü, Su Ürünleri Merkez Araştırma Enstitüsü Müdürlüğü, Trabzon, 114 sy.

Gönener, S., \& Bilgin, S. (2006). Karadeniz'de (Sinop-Yakakent Bölgesi) ticari dip trolü ile avlanabilir balık biyokütle ve yoğunluk dağılımları. Fırat Üniversitesi Fen ve Mühündislik Bilimleri Dergisi, 18(3), 305-312.

Gönener, S., \& Bilgin, S. (2010). Karadeniz'de (Sinop-Inceburun) ticari dip trolü ile avlanabilir balık biyokütle ve yoğunluk dağılımları. Journal of Fisheries Sciences, 4(3), 195.

Granadeiro, J. P., \& Silva, M. A. (2000). The use of otoliths and vertebrae in the identification and size-estimation of fish in predator-prey studies. Cybium, 24(4), 383-393.

Hehir, I. (2003). Age, growth and reproductive biology of whiting Merlangius merlangus (Linnaeus 1758) in the Celtic Sea, Masters Thesis in Fisheries Biology Galway-Mayo Institute of Technology and The Marine Institute, $210 \mathrm{pp}$.

Hunt, J. J. (1992). Morphological Characteristics of Otoliths for Selected Fish in the Northwest Atlantic. Journal of Northwest Atlantic Fishery Science, 13, 63-75. [CrossRef]

Ismen, A. (1995). The Biology and population parameters of the whiting (Merlangius merlangus euxinus Nordmann) in the Turkish coast of the Black Sea. PhD. thesis, Middle East Technical University, Mersin, 50994. [CrossRef]

İsmen, A. (2002). A preliminary study on the population dynamics parameters of whiting, (Merlangus merlangus euxinus) in the Turkish Black Sea Coastal waters. Turkish Journal of Zoology, 26, 157-166.

Javor, B., Lo, N., \& Vetter, R. (2011). Otolith morphometrics and population structure of Pacific sardine (Sardinops sagax) along the west coast of North America. Fishery Bulletin, 109, 402-15.

Jobling, M. \& Breiby, A. (1986). The use and abuse of fish otoliths in studies of feeding habits of marine piscivores. Sarsia, 71, 265-274. [CrossRef]

Kalaycı, F., Samsun, N., Bilgin S., \& Samsun O. (2007). Length-weight relationship of 10 fish species caught by bottom trawl and midwater trawl from the Middle Black Sea, Turkey. Turkish Journal of Fisheries and Aquatic Sciences, 7, 33-36.

Kontaş, S., Bostancı, D., Yedier, S., Kurucu, G., \& Polat, N. (2018). Investigation of fluctuating asymmetry in the four otolith characters of Merlangius merlangus collected from Middle Black Sea. Turkish Journal of Maritime and Marine Sciences, 4(2), 128-138.

Mazlum, R.E., \& Bilgin, S. (2014). Age, growth, reproduction and diet of the whiting, Merlangius merlangus euxinus (Nordmann, 1840), in the southeastern Black Sea. Cahiers de Biologie Marine, 55, 463-474.

Özdemir, S., Erdem, Y., \& Sümer, Ç. (2006). Kalkan (Psetta maxima, Linneaus, 1758) ve mezgit (Merlangius merlangus euxinus, Nordman 1840) balıklarının yaş ve boy kompozisyonundan hesaplanan bazı populasyon parametrelerinin karşılaştıııması. OMÜ Ziraat Fakültesi Dergisi, 21(1), 71-75.

Pitcher, K. W. (1980). Stomach contents and feces as indicators of harbor seal Phoca vitulina foods in the Gulf of Alaska. Fishery Bulletin, 78, 797-798.

Polat, N., \& Gümüş, A. (1996). Ageing of whiting (Merlangius merlangus euxinus Nord. 1840) based on broken and burned otolith. Fisheries Research, 28, 231-236. [CrossRef]

R Core Team (2018). R: A Language and Environment for Statistical Computing. R Foundation for Statistical Computing, Vienna. https:// www.R-project.org 
Reşat, H. (2013). Sinop yöresinde avlanan mezgit (Merlangius merlangus) ve barbunya (Mullus barbatus) balıklarının bazı üreme özelliklerinin belirlenmesi. Yüksek Lisans Tezi, Sinop Üniversitesi, Fen Bilimleri Enstitüsü, Sinop, 343186.

Samsun, O., Özdamar, E., \& Aral, O. (1994). Orta Karadeniz trol sahalarında dip trolü ile avlanan mezgit (Gadus merlangus euxinus Nordmann, 1840) balığının balıkçılık biyolojisi açısından araştırılması. Ege Üniversitesi Fen Fakültesi Dergisi, 16(1), 1003-1011.

Samsun S. (2005). Mezgit balığının (Gadus merlangus euxinus, Nordmann, 1840) bazı üreme ve beslenme özellikleri üzerine bir araştırma. Doktora Tezi, Ondokuz Mayıs Üniversitesi, Fen Bilimleri Enstitüsü, Samsun, 198761.

Samsun S., Erdem Y., \& Kalaycı F. (2011). Feeding regime of whiting (Gadus merlangus euxinus Nordmann, 1840) in Turkish Middle Black Sea Coast. Turkish Journal of Fisheries and Aquatic Sciences, 11(4), 515-522.

Smale, M. J., Watson, G., \& Hecht, T. (1995). Otolith atlas of Southern African marine fishes. South African Institute for Aquatic Biodiversity, 418p. [CrossRef]

Tuset, V. M., Lombarte, A., \& Assis, C. A. (2008). Otolith atlas for the western Mediterranean, north and central eastern Atlantic. Scientia Marina, 72S1, 7-198. [CrossRef]
Tuset V. M., Lozano I. J., González J. A., Pertusa J. F., \& GarcíaDíaz M. M. 2003. Shape indices to identify regional differences in otolith morphology of comber, Serranus cabrilla (L., 1758). Journal of Applied Ichthyology, 19(2), 88-93. [CrossRef]

Van, A., Gümüş A., \& Süer S. (2019). Length-weight relationships and condition factors of 15 fish species from KizilirmakYesilirmak Shelf Area, the Southeastern Black Sea. Natural and Engineering Sciences, 4(1), 21-27. [CrossRef]

Whitehead, P. J. P., Bauchot, M. L., Hureau, J. C., Nielsen, J., \& Tortonese, E. (1986). Fishes of the North-Eastern Atlantic and the Mediterranean. UNESCO ed. Printed by Richard Clay Ltd. U.K,. 510p. [CrossRef]

Yildiz, T., Zengin, M., Uzer, U., Akpinar, I.O., \& Karakulak, F.S. (2018). Length-weight relationships for 24 fish species collected from the western Black Sea (Turkey). Cahiers de Biologie Marine, 59, 159-165.

Yıldız, T., \& Karakulak, F.S. (2019). Age, growth and mortality of whiting (Merlangius merlangus Linnaeus, 1758) from the Western Black Sea, Turkey. Turkish Journal of Fisheries and Aquatic Sciences, 19(9), 793804. [CrossRef]

Zar, J.H. (2010). Biostatistical Analysis. Prentice Hall, London, 944 pp. 